\title{
CONTROLLING THE STRUCTURE OF WEAR-RESISTANT STEELS 150KhNML AND Kh12MFL BY HIGH-TEMPERATURE QUENCHING AND COLD TREATMENT
}

\author{
M. A. Filippov ${ }^{1}$, M. A. Gervasiev ${ }^{1}$, S. M. Nikiforova ${ }^{1}$, Yu. V. Khudorozhkova ${ }^{2}$, \\ G. N. Plotnikov ${ }^{3}$, S. Kh. Estemirova ${ }^{4}$, V. V. Legchilo ${ }^{1}$ \\ ${ }^{1}$ Ural Federal University named after the First President of Russia B. N. Yeltsin, 19 Mira st., \\ Ekaterinburg, Russian Federation \\ ${ }^{2}$ Institute of Engineering Science, Ural Branch of the Russian Academy of Sciences, \\ 34 Komsomolskaya st., Ekaterinburg, Russian Federation \\ ${ }^{3}$ PromTekhnoTsentr Industrial Technological Center, Ekaterinburg, Russian Federation \\ ${ }^{4}$ Institute of Metallurgy, Ural branch of Russian Academy of Sciences, \\ 101 Amundsena st., Ekaterinburg, Russian Federation \\ *Corresponding autor. E-mail: filma1936@mail.ru; \\ address for correspondence: 34, ul. Komsomolskaya, 620049, Ekaterinburg, Russian Federation. \\ Tel.: +7 (343) 37450 51; fax: +7 (343) 3745330
}

The paper studies the effect of quenching in a wide range of temperatures on the quantity of metastable residual austenite, its stability, hardening and wear resistance in the process of abrasive wear of high-carbon tool steels of the pearlitic and ledeburitic classes - 150KhNML and Kh12MFL. Despite decreasing initial hardness with increasing quenching temperature, the abrasive wear resistance of the steels increases, this being due to a change in the quantity, composition and deformation stability of residual austenite. The increase in the relative wear resistance of both steels with increasing quenching temperature correlates with hardenability determined by measuring the microhardness of the gauge surface after wear. The cold treatment of the Kh12MFL steel after hightemperature quenching additionally enhances its abrasive wear resistance by $25 \%$ due to the formation of $15 \%$ of high-carbon-chromium cryogenic martensite and increases the initial hardness to $60 \mathrm{HRC}$ with the preservation of $20 \%$ of residual metastable austenite and carbides.

Keywords: abrasive wear, hardening, wear resistance, martensite, residual metastable austenite, carbides.

DOI: $10.17804 / 2410-9908.2017 .1 .043-054$

\section{References}

1. Shabashov V.A., Korshunov L.G., Mukoseev A.G., Sagaradze V.V., Makarov A.V., Pilyugin V.P., Novikov S.I., Vildanova N.F. Deformation-induced phase transitions in a highcarbon steel. Materials Science and Engineering: A, 2003, vol. 246, pp.196-207. DOI: 10.1016/S0921-5093(02)00549-X.

2. Filippov M.A., Gervasiev M.A., Khudorozhkova Yu.V., Legchilo V.V. Effect of quenching temperature on the phase composition, structure and wear resistance of the 150KhNM steel. Izvestiya vysshykh uchebnykh zavedeniy. Chernaya metallurgiya, 2013, no. 11, pp. 14-16. (In Russian).

3. Gulyaev A.P. Metallovedenie [Metal Science]. M., Metallurgiya Publ., 1986, 544 p. (In Russian).

4. Firouzdor V., Nejati E., Khomamizadeh F. Effect of deep cryogenic treatment on wear resistance and tool life of M2 HSS drill. Journal of Materials Processing Technology, 2008, vol. 206, pp. 467-472. DOI: 10.1016/j.jmatprotec.2007.12.072. 
5. $\quad$ Khrushchev M.M., Babichev M.A. Abrazivnoe iznashivanie [Abrasive Wear]. M., Nauka Publ., 1979, 252 p. (In Russian).

6. Korshunov L.G. Iznashivanie metallov pri trenii. V. 1, book 2 [Frictional Wear of Metals]. M., Metallurgiya Publ., 1991, pp. 387-413. (In Russian).

7. Filippov M.A., Litvinov V.S., Nemirovsky Yu. R. Stali s metastabilnym austenitom [Steels with Metastable Austenite]. M., Metallurgiya Publ., 1988, 257 p. (In Russian).

8. Ivanova V.S. Synergetics in metal science. Metallovedenie i termicheskaya obrabotka metallov, 2005, no. 2, pp. 12-19.

9. Bernshtein M.L. Struktura deformirovannykh metallov [Structure of Deformed Metals]. M., Metallurgiya Publ., 1977, pp. 490. 
Подана в журнал: 25.02 .2017

УДК 669.15:620.1:621.78

DOI: $10.17804 / 2410-9908.2017 .1 .043-054$

\title{
РЕГУЛИРОВАНИЕ СТРУКТУРЫ ИЗНОСОСТОЙКИХ СТАЛЕЙ 15ОХНМЛ И Х12МФЛ ВЫСОКОТЕМПЕРАТУРНОЙ ЗАКАЛКОЙ И ОБРАБОТКОЙ ХОЛОДОМ
}

\author{
М. А. Филиппов, М. А. Гервасьев, С. М. Никифорова ${ }^{1}$, Ю. В. Худорожкова ${ }^{2}$, \\ Г. Н. Плотников ${ }^{3}$, С. Х. Эстемирова ${ }^{4}$, В. В. Легчило ${ }^{1}$ \\ ${ }^{I}$ Уральский федеральный университет имени первого Президента России Б.Н. Ельцина, ул. Мира, 19, \\ Екатеринбург, Российская Федерация \\ ${ }^{2}$ Федеральное государственное бюджетное учреждение науки Институт матиноведения \\ Уральского отделения Российской академии наук, ул. Комсомольская, 34, \\ Екатеринбург, Российская Федерациия \\ ${ }^{3}$ «ромТехноЦентр», г. Екатеринбург, Российская Федераџия \\ ${ }^{4}$ Федеральное государственное бюджетное учреждение науки Институт металлургии \\ Уральского отделения Российской академии наук, ул. Амундсена, д. 101, \\ Екатеринбург, Российская Федерация \\ *Ответственный автор. Электронная почта: filma1936@mail.ru; \\ адрес для переписки ул. Комсомольская, 34, 620049, Екатеринбург, Российская Федерация. \\ Телефон: +7 (343) 374-50-51; факс: +7 (343) 374-53-30
}

Изучено влияние закалки в широком диапазоне температур на количество метастабильного остаточного аустенита, его стабильность, упрочнение и износостойкость в процессе абразивного изнашивания высокоуглеродистых инструментальных сталей перлитного и ледебуритного классов - 150ХНМЛ и Х12МФЛ. Несмотря на снижение исходной твёрдости при повышении температуры закалки абразивная износостойкость сталей возрастает, что связано с изменением количества, состава остаточного аустенита и его деформационной стабильности. Увеличение относительной износостойкости обеих сталей с повышением температуры закалки коррелирует со способностью к упрочнению, определяемой посредством измерения микротвёрдости рабочей поверхности после изнашивания. Обработка холодом стали Х12МФЛ после высокотемпературной закалки позволяет дополнительно повысить абразивную износостойкость на $25 \%$ за счёт образования $15 \%$ высокоуглеродисто-хромистого мартенсита охлаждения и повышения начальной твёрдости до $60 \mathrm{HRC}$ с сохранением 20 \% остаточного метастабильного аустенита и карбидов.

Ключевые слова: абразивное изнашивание, закалка, износостойкость, мартенсит, остаточный метастабильный аустенит, карбиды.

\section{1. Введение}

Одна из основных проблем материаловедения - повышение сопротивления абразивному изнашиванию узлов и деталей машин, поскольку этот вид изнашивания является наиболее распространённой причиной преждевременного выхода из строя многих машин и агрегатов горно-металлургического, строительно-дорожного оборудования, промышленности стройматериалов, буровой техники. Проблема борьбы с этим видом изнашивания решается в большинстве случаев с помощью использования высокоуглеродистых штамповых или валковых сталей, например 150ХНМЛ, Х12МФЛ, а иногда белых износостойких чугунов и наплавочных сплавов. Эффективными материалами в этих условиях служат сплавы с карбидным упрочнением и металлической основой, состоящей из мартенсита с некоторым ко-

Filippov M.A. et al. / Controlling the structure of wear-resistant steels 150KhNML and Kh12MFL

by high-temperature quenching and cold treatment 
личеством метастабильного остаточного аустенита $[1,2]$. К деталям, испытывающим в эксплуатации циклические нагрузки при повышенном переменном давлении в сочетании с интенсивным абразивным воздействием промывочной жидкости, содержащей твёрдые частицы, относятся, например цилиндровые втулки буровых насосов. Срок службы втулок не превышает 100-200 ч вследствие гидроабразивного изнашивания и появления недопустимо больших зазоров в узле трения втулка-поршень.

В связи с необходимостью разработки технологии производства цилиндровых втулок буровых насосов и аналогичных по условиям работы деталей из износостойких сталей цель работы состояла в изучении влияния температуры нагрева образцов из сталей 150ХНМЛ и Х12МФЛ под закалку на достижение максимальной износостойкости в сочетании с конструктивной прочностью. Варьирование температуры закалки и последующего отпуска стали Х12МФЛ позволяет также получить минимальные изменения размеров изделий из этой стали при термообработке [3]. Дополнительные возможности повышения абразивной износостойкости состоят в обработке холодом высокоуглеродистых сталей вследствие прироста количества мартенсита охлаждения $[3,4]$.

\section{2. Методика проведения исследований}

Из литых трубных заготовок сталей перлитного (150ХНМЛ) и ледебуритного (Х12МФЛ) классов после нормализации и отпуска были изготовлены образцы размером 10x10x25 мм для изучения микроструктуры и испытаний на абразивное изнашивание.

Температуру нагрева образцов под закалку изменяли в широком диапазоне $\left(850 \div 1170{ }^{\circ} \mathrm{C}\right)$. Выдержка при температуре нагрева составляла 30 мин, охлаждение в масле.

Оценка износостойкости образцов производилась с помощью методики изнашивания по закреплённому абразиву, близкой к методике, описанной в работах $[2,5]$. Образцы с площадью рабочей части 10х10 мм совершали возвратно-поступательное движение по шлифовальной бумаге 14А32MH481 (ГОСТ 6456-82) на корундовой основе. Нагрузка на образец составляла 10 кг (удельная нагрузка 1 МПа).

Абразивная износостойкость определялась по результатам двух параллельных испытаний, сравнение результатов производили через относительные единицы:

$$
\varepsilon=\Delta \mathrm{M}_{3} / \Delta \mathrm{M}_{\mathrm{o}}
$$

где $\varepsilon$ - относительная износостойкость; $\Delta \mathrm{M}_{\ni}$ - потеря массы образца-эталона - валковой стали 9Х5МФС после закалки от $900{ }^{\circ} \mathrm{C}$ и низкого отпуска $\left(0,4100\right.$ г) [1]; $\Delta \mathrm{M}_{\mathrm{o}}$ - потеря массы испытуемого образца, которая составляла менее $1 \%$ на пути трения 30 м [2].

Фазовый анализ поверхности образцов после изнашивания определяли методом рентгеноструктурного анализа, упрочнение рабочей поверхности оценивали по приросту микротвёрдости при нагрузке $0,49 \mathrm{H}$.

\section{3. Результаты испытаний и их обсуждение}

Исходная структура образцов стали 150ХНМЛ с твёрдостью $300 \mathrm{HV}$ состоит из небольшого количества неравномерно распределённых участков карбидной эвтектики (ледебурита) (в среднем около 5 \%), вторичного цементита по границам и внутри зёрен и продуктов диффузионного распада аустенита (рис. 1 a). Образцы стали Х12МФЛ имеют ячеистодендритную структуру, состоящую из аустенитно-карбидной эвтектики в количестве около 25 \%, образовавшейся по границам первичных кристаллов аустенита, продуктов диффузионного распада аустенита и вторичных карбидов внутри ячеек (рис. 2).

Повышение температуры закалки оказывает существенное влияние на структуру стали 150ХНМЛ. При температуре нагрева под закалку $850{ }^{\circ} \mathrm{C}$ в структуре образцов стали 150ХНМЛ наряду с мартенситом сохраняется избыточный цементит в виде сетки

Filippov M.A. et al. / Controlling the structure of wear-resistant steels 150KhNML and Kh12MFL

by high-temperature quenching and cold treatment 
ittp.//dream-journal.or"]

по границам и пластин внутри зёрен (рис. 1 б). В результате повышения температуры нагрева до $1000{ }^{\circ} \mathrm{C}$ структура стали 150 ХНМЛ представлена мелкоигольчатым мартенситом с равномерно распределенными карбидами и раздробленной карбидной сеткой, при температуре выше $1000{ }^{\circ} \mathrm{C}$ заметно увеличивается размер кристаллов мартенсита; мартенсит становится крупноигольчатым (рис. 1 в). Известно, что при увеличении температуры нагрева под закалку также изменяется субструктура валковой стали 9Х5МФС. При температуре аустенитизации выше $1000{ }^{\circ} \mathrm{C}$ реечный мартенсит постепенно переходит в двойникованный [2]. Видно также, что с увеличением температуры аустенитизации наблюдается закономерное увеличение размера зерна (рис. 1 2), особенно заметное после нагрева стали 150ХНМЛ при температурах выше $1000{ }^{\circ} \mathrm{C}$ в связи с тем, что при этих температурах происходит интенсивное растворение сетки вторичного цементита. По данным [2], температура нагрева $1050{ }^{\circ} \mathrm{C}$ превышает точку $\mathrm{A}_{\mathrm{cm}}$ стали 150 ХНМЛ.

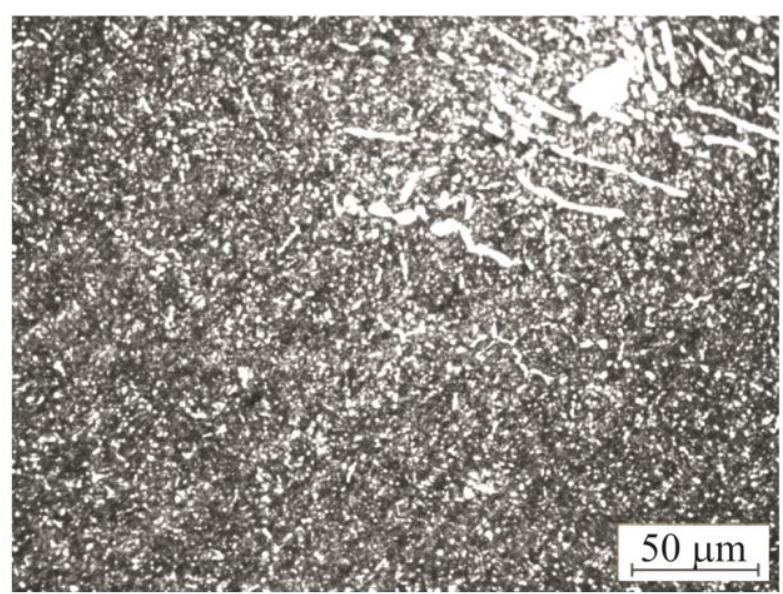

$a$

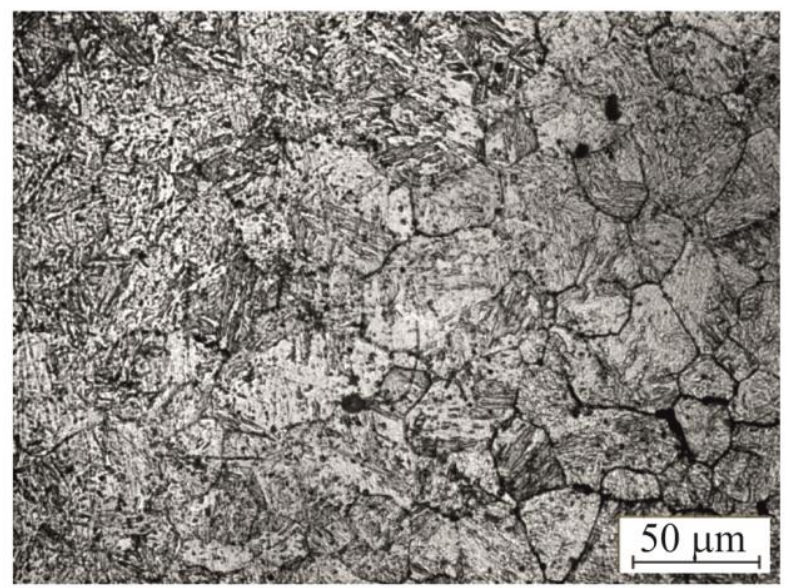

B

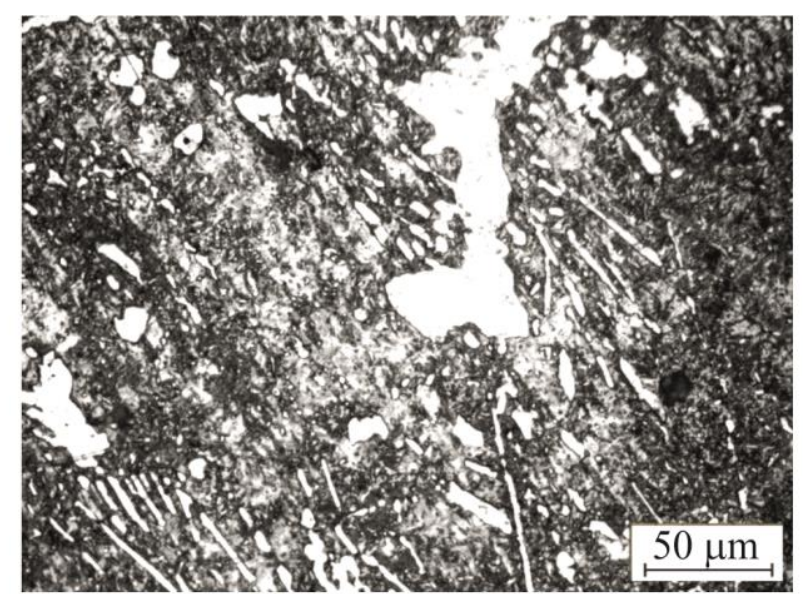

$\sigma$

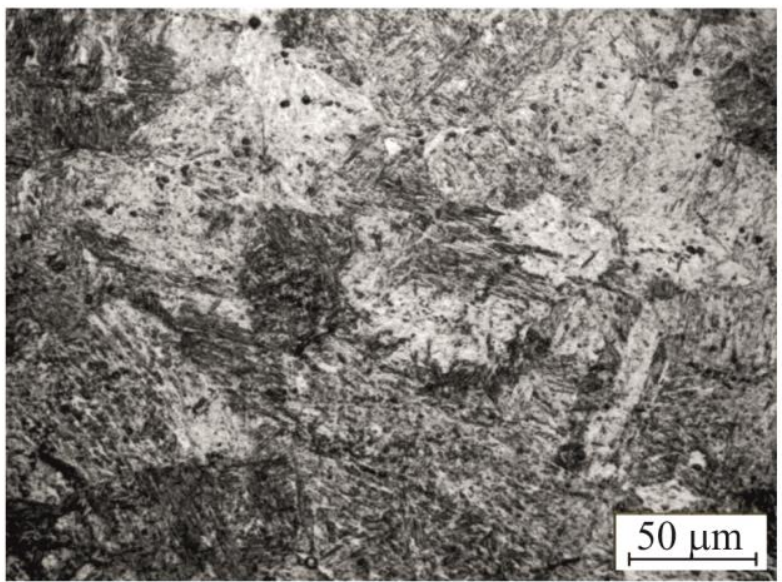

2

Рис. 1. Микроструктура стали 150ХНМЛ после закалки от различных температур: $a$ - исходная структура; $\sigma-850{ }^{\circ} \mathrm{C} ; \mathrm{B}-1000{ }^{\circ} \mathrm{C} ; 2-1170{ }^{\circ} \mathrm{C}$

Повышение температуры нагрева под закалку вызывает постепенное растворение вторичных карбидов $\mathrm{M}_{3} \mathrm{C}$ - в стали 150 ХНМЛ и $\mathrm{M}_{7} \mathrm{C}_{3}$ в стали Х12МФЛ, и это приводит к увеличению количества остаточного аустенита в стали 150ХНМЛ от 0 до $25 \%$ при $\mathrm{t}_{\text {зак }}=900{ }^{\circ} \mathrm{C}$ и $1170{ }^{\circ} \mathrm{C}$ соответственно и в стали Х12МФЛ - от 0 до $60 \%$ при тех же температурах аустенитизации (рис. 3 и 4).

Filippov M.A. et al. / Controlling the structure of wear-resistant steels 150KhNML and Kh12MFL by high-temperature quenching and cold treatment 
hittp://dream-journal.or"'

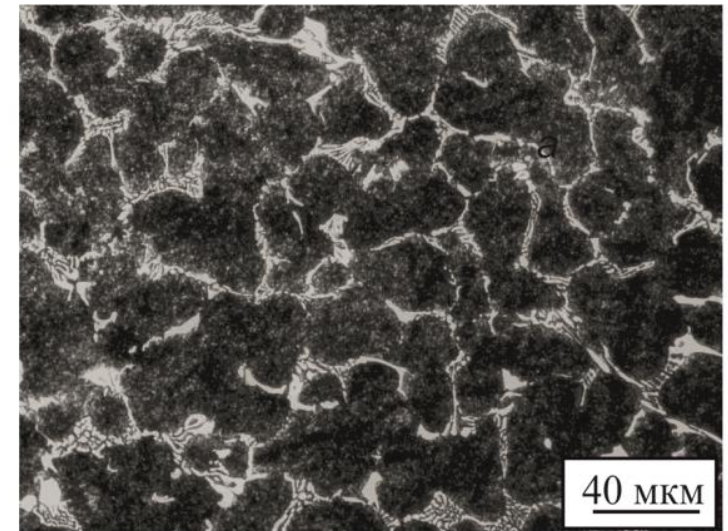

$a$

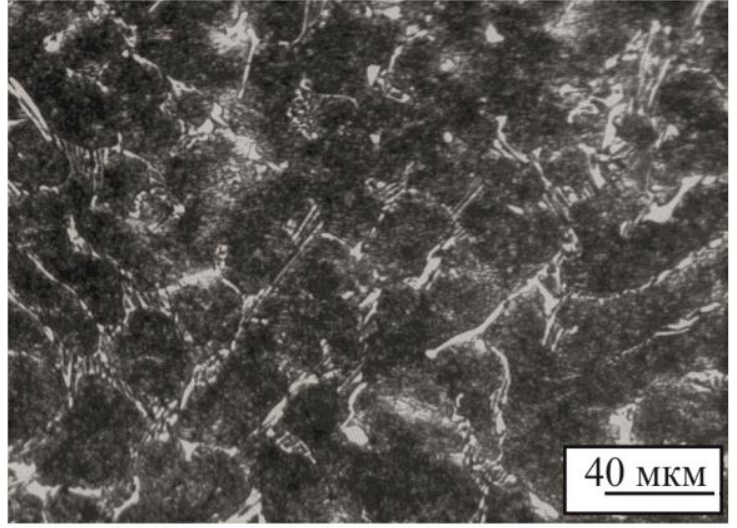

$\sigma$

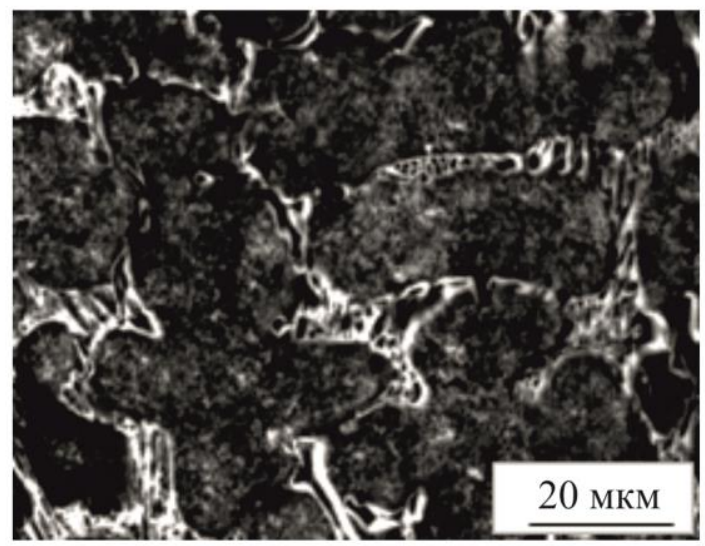

B

Рис. 2. Микроструктура стали Х12МФЛ после закалки от различных температур: $a-1000{ }^{\circ} \mathrm{C} ; \sigma-1100{ }^{\circ} \mathrm{C} ; в-1170{ }^{\circ} \mathrm{C}$

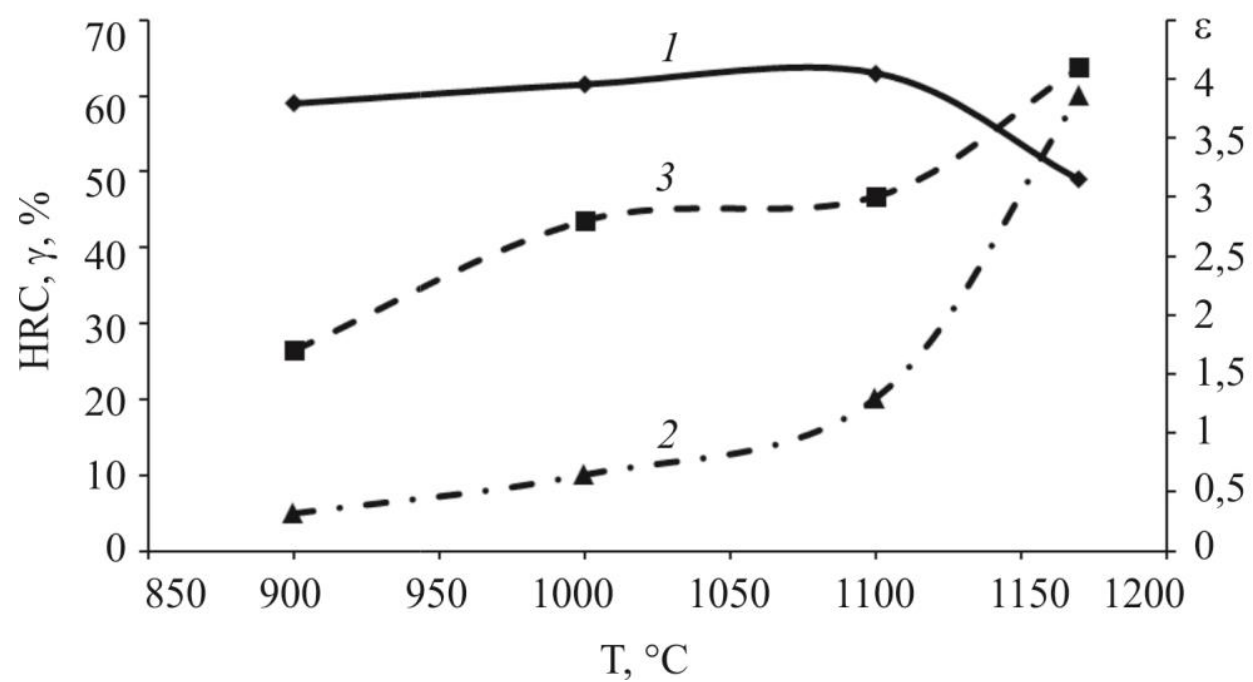

Рис. 3. Зависимость количества остаточного аустенита, твёрдости и относительной абразивной износостойкости от температуры нагрева под закалку стали Х12МФЛ: 1 - твердость (HRC); 2 - количество остаточного аустенита $\left(\gamma_{\text {ост }}, \%\right)$; 3 - относительнаяизносостойкость $(\varepsilon)$

Filippov M.A. et al. / Controlling the structure of wear-resistant steels 150KhNML and Kh12MFL by high-temperature quenching and cold treatment 


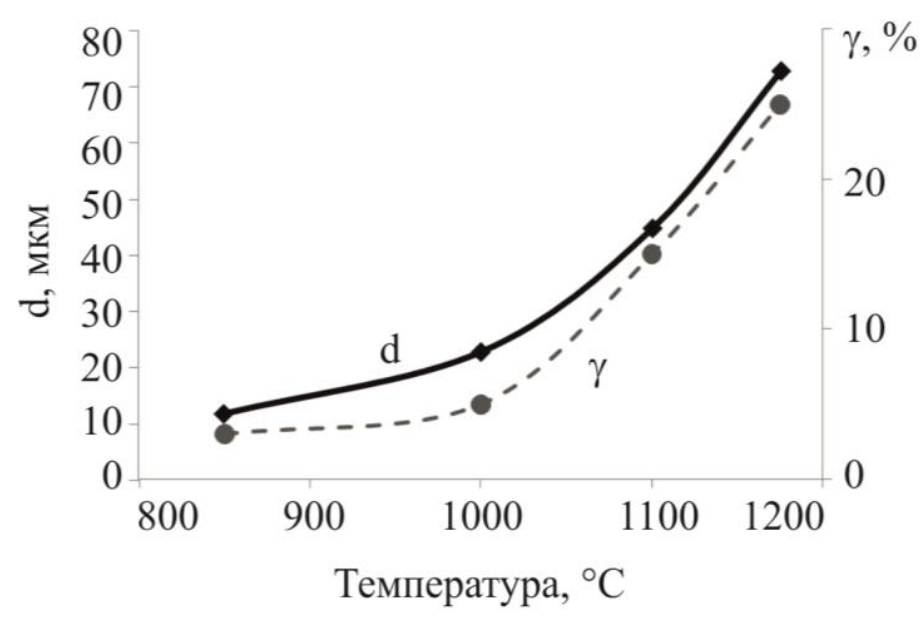

$a$

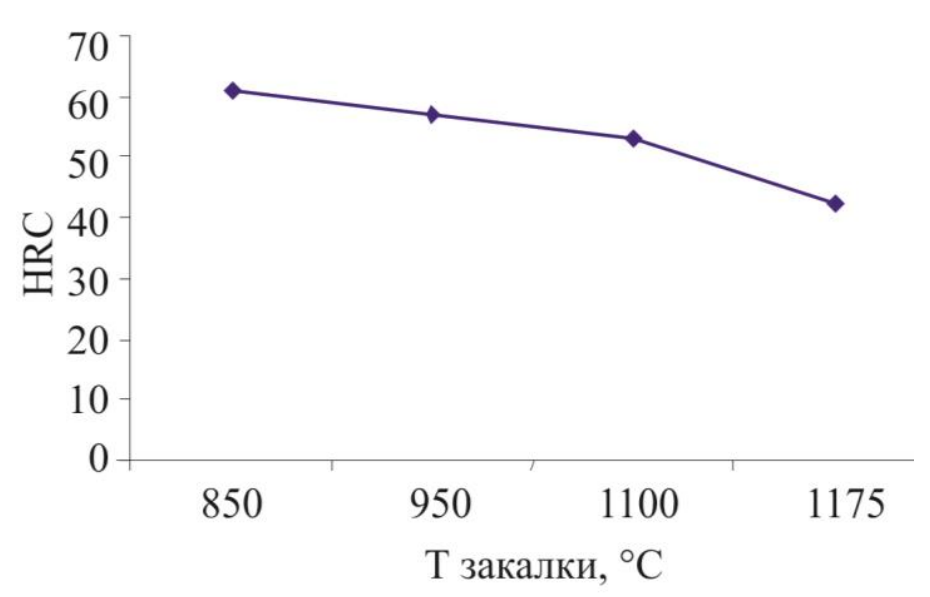

$\sigma$

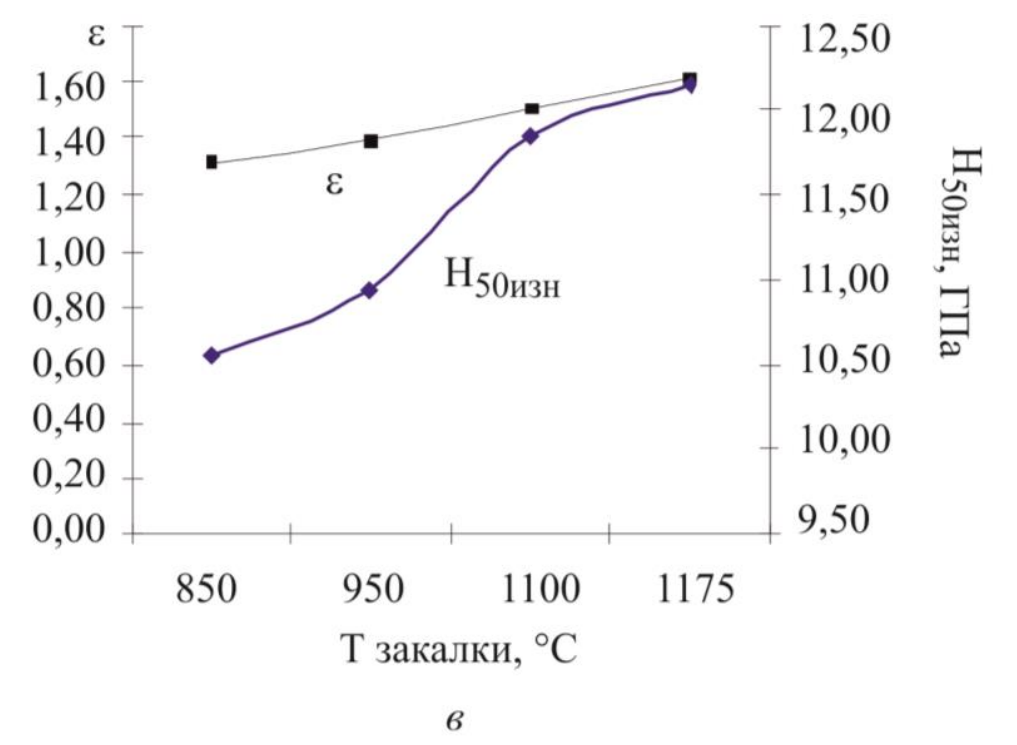

Рис. 4. Влияние температуры нагрева под закалку стали 150ХНМ на размер зерна (d) и количество остаточного аустенита $(\gamma)-a$; твёрдость $(\mathrm{HRC})-\sigma$;

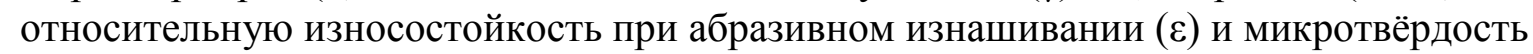
на поверхности изнашивания $\left(\mathrm{H}_{50 \text { изн }}\right)-8$

Прогрессирующее по мере повышения $\mathrm{t}_{\text {зак }}$ растворение вторичных карбидов и насыщение твердого раствора углеродом и хромом стали 150ХНМЛ обусловливает снижение твёрдости HRC, сначала незначительное а вследствие увеличения количества остаточного аустенита после нагрева выше $1100{ }^{\circ} \mathrm{C}$ - уменьшение твёрдости от $53 \mathrm{HRC}$ (при $\mathrm{t}_{\text {зак }}=1100{ }^{\circ} \mathrm{C}$ ) до $42 \mathrm{HRC}$ (при $\mathrm{t}_{\text {зак }}=1170{ }^{\circ} \mathrm{C}$ ) (рис. 4 ). Величина твёрдости зависит от соотношения двух основных, противоположно действующих факторов: увеличения количества остаточного аустенита, снижающего твёрдость, с одной стороны, и рост концентрации углерода в мартенсите - с другой. Начиная с температур аустенитизации $1000{ }^{\circ} \mathrm{C}$ для стали 150 ХНМЛ первый фактор превалирует, что вызывает снижение твёрдости сталей после закалки. Качественно аналогичное изменение фазового состава по мере повышения температуры нагрева под закалку обнаружила и сталь Х12МФЛ, уменьшение твёрдости в которой составило от 59 HRC (при $\mathrm{t}_{\text {зак }}=1100{ }^{\circ} \mathrm{C}$ ) до $49 \mathrm{HRC}$ при температуре нагрева под закалку $1170{ }^{\circ} \mathrm{C}$ (рис. 3). Однако металлографическая картина изменения структуры в этой стали значительно отличается от стали 150ХНМЛ, так как все структурные изменения происходят внутри ячеек - видно уменьшение количества вторичных карбидов и появление участков остаточного аустени- 
та, в то время как размер ячеек, окружённых эвтектикой, остаётся неизменным, составляя 20-30 мкм.

Насыщение аустенита углеродом и легирующими элементами приводит к повышению устойчивости переохлажденного аустенита, снижению критической скорости закалки и, как следствие, увеличению прокаливаемости.

Результаты испытаний образцов сталей 150ХНМЛ и Х12МФЛ на абразивное изнашивание после закалки от различных температур представлены в табл. 1 и на рис. 3 и 4.

В противоположность твёрдости, износостойкость сталей 150ХНМЛ и Х12МФЛ возрастает при повышении температуры нагрева под закалку, особенно заметное - начиная с $1100^{\circ} \mathrm{C}$.

Отмеченные особенности влияния $\mathrm{t}_{\text {зак }}$ на износостойкость сталей 150ХНМЛ и Х12МФЛ подтверждают литературные данные о положительной роли метастабильного остаточного аустенита определённого состава по отношению к деформационному мартенситному превращению в обеспечении высокой абразивной износостойкости [1]. Рост износостойкости обусловлен увеличением количества деформационного $\alpha$-мартенсита с высоким со-

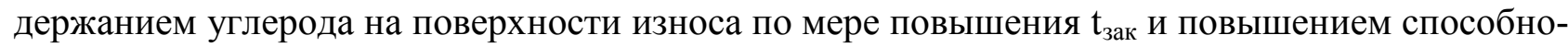
сти остаточного аустенита к фрикционному упрочнению (табл. 1; рис. 4). Более значительное увеличение износостойкости с повышением температуры аустенитизации происходит у стали Х12МФЛ, в которой превращается в мартенсит до 50 \% остаточного аустенита.

Наибольшая износостойкость сталей 150ХНМЛ и Х12МФЛ обеспечивается после закалки от $1170{ }^{\circ} \mathrm{C}$. Данные рис. 3 и 4 и табл. 1 указывают на корреляцию между максимальными значениями относительной износостойкости и микротвердости рабочей поверхности обеих сталей после изнашивания. В связи с этим для оценки сопротивления изнашиванию целесообразно использовать величину эффективной микротвердости (HV эфф), которая складывается из исходной микротвердости $\left(\mathrm{HV}_{0}\right)$ и прироста микротвердости $(\Delta \mathrm{HV})$ на поверхности изнашивания [6]. Эффективная микротвёрдость служит комплексной характеристикой прочности поверхностного слоя материала, учитывающей, наряду с исходной твёрдостью, упрочнение, вносимое фазовыми превращениями в процессе изнашивания, и деформационное упрочнение присутствующих и вновь образующихся фаз, в частности, упрочнение от образования мартенсита деформации.

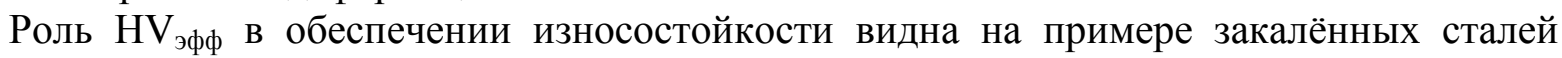
150ХНМЛ и Х12МФЛ: после закалки от $1170{ }^{\circ} \mathrm{C}$ они имеют минимальную исходную твёрдость, однако обладают наибольшим сопротивлением абразивному изнашиванию (табл. 1). Это связано с высокой способностью метастабильного остаточного аустенита к деформационному упрочнению, которое определяется по приросту микротвёрдости рабочей поверхности образцов, соответствующему $500 \mathrm{HV}_{50}$ (табл. 1).

В сталях со структурой мартенсита энергия внешнего воздействия от вдавливания и движения абразивных частиц расходуется на упруго-пластическую деформацию кристаллов, повышение плотности дислокаций до критической величины и образование микротрещин с последующим их развитием и разрушение по механизмам царапания и микрорезания. В сталях со структурой метастабильного аустенита часть энергии внешнего воздействия от внедрения абразивных частиц рассеивается в результате фазового перехода - развития процесса деформационного мартенситного превращения. Образование дисперсных кристаллов мартенсита деформации по сдвиговому механизму сопровождается релаксацией микронапряжений в момент превращения (микро-ТРИП-эффект), а в результате $\gamma \rightarrow \alpha_{\mathrm{M}}$ перехода обеспечивается высокая прочность рабочей поверхности сталей и работоспособность их в условиях абразивного изнашивания [7].

С позиций синергетического подхода метастабильный аустенит в наибольшей степени среди других структурных составляющих обладает свойствами динамических структур: адаптации, самовоспроизведения, изменчивости, отбора наиболее устойчивой структуры, способности к упрочнению [8].

Filippov M.A. et al. / Controlling the structure of wear-resistant steels 150KhNML and Kh12MFL

by high-temperature quenching and cold treatment 
Таблица 1 - Результаты испытаний образцов сталей 150ХНМЛ и Х12МФЛ на абразивное изнашивание после закалки в масло от разных температур

\begin{tabular}{|l|l|l|l|l|}
\hline $\begin{array}{c}\text { Режим } \\
\text { термообработки }\end{array}$ & \multicolumn{1}{|c|}{$\begin{array}{c}\text { Потери массы, } \\
\Delta \mathrm{M}, \Gamma\end{array}$} & HRC & $\varepsilon$ & $\mathrm{H}_{\text {пов., ГПа }}$ \\
\hline \multicolumn{5}{|c|}{ Сталь 150ХНМЛ } \\
\hline Закалка с 850 C & 0,2733 & 61 & 1,5 & 10.2 \\
\hline Закалка с 1000 C & 0,2215 & 57 & 1,8 & 10,9 \\
\hline Закалка с 1100 С & 0,1997 & 53 & 2,0 & 11,8 \\
\hline Закалка с 1170 С & 0,1820 & 42 & 2,2 & 12,1 \\
\hline \multicolumn{5}{|c|}{ Сталь Х12МФЛ } \\
\hline Закалка с 900 С & 0,2355 & 59 & 1,7 & 10.5 \\
\hline Закалка с 1000 С & 0,1424 & 61,5 & 2,8 & 11,1 \\
\hline Закалка с 1100 С & 0,1366 & 63 & 3,0 & 12,0 \\
\hline Закалка с 1170 С & 0,0978 & 49 & 12,2 \\
\hline
\end{tabular}

Альтернативным методом регулирования соотношения мартенсита охлаждения и остаточного аустенита, начальной твёрдости и износостойкости сталей служит обработка холодом после высокотемпературной закалки, в результате применения которой можно получить дополнительное количество высокоуглеродистого мартенсита охлаждения и повысить начальную твёрдость, сохранив некоторое количество метастабильного остаточного аустенита.

Обработка холодом образцов стали Х12МФЛ с большим количеством остаточного аустенита проводилась в 2 этапа:

1) закалка после нагрева при температуре $1170{ }^{\circ} \mathrm{C}$ в течение 20 мин, охлаждение в масле;

2) охлаждение в охлаждающей среде камеры криостата с выдержкой при заданной температуре в течение 20 мин, отогрев до комнатной температуры, низкий отпуск при температуре $200{ }^{\circ} \mathrm{C}$ в течение 2 ч.

По изменению твердости в зависимости от температуры охлаждения можно утверждать, что мартенситное превращение заканчивается в основном при охлаждении до $-70{ }^{\circ} \mathrm{C}$ (при понижении температуры от комнатной до $-70{ }^{\circ} \mathrm{C}$ твердость стремительно растет, а при дальнейшем охлаждении до температуры жидкого азота значения твердости остаются практически неизменными (табл. 2) с получением мартенсита с повышенной концентрацией углерода и хрома. Медленный отогрев до комнатной температуры не изменяет твёрдости и количества мартенсита.

\section{Таблица 2 - Изменение твердости стали Х12МФЛ в зависимости от температуры охлаждения, HRC}

\begin{tabular}{|c|l|l|c|c|c|}
\hline № & Марка & Режим ТО* & $\begin{array}{c}\text { Твердость } \\
\text { после ТО }\end{array}$ & $\begin{array}{c}\text { Твердость } \\
\text { после ТО + OX } \\
\left(-70{ }^{\circ} \mathrm{C}\right)\end{array}$ & $\begin{array}{c}\text { Твердость } \\
\text { после ТО + ОХ } \\
\left(-196^{\circ} \mathrm{C}\right)\end{array}$ \\
\hline 1 & Х12МФЛ & Закалка $1170^{\circ} \mathrm{C}$ & 42 & 62 & 63 \\
\hline 2 & Х12МФЛ & Закалка $1100^{\circ} \mathrm{C}$ & 56 & 58 & 58 \\
\hline
\end{tabular}

*ТО - термическая обработка;

** $\mathrm{OX}$ - обработка холодом.

Filippov M.A. et al. / Controlling the structure of wear-resistant steels 150KhNML and Kh12MFL 
Соотношение мартенсита охлаждения, обогащенного углеродом и хромом, и остаточного аустенита определяли рентгеновским методом. Из рентгеновских дифрактограмм (рис. 5) видно, что увеличивается содержание мартенсита охлаждения до 80 \% с сохранением доли остаточного аустенита до 20 \%. Брэгговские пики мартенсита более широкие, чем пики аустенита. Одной из причин уширения пиков является рост микродеформаций в материале. В исследованных полифазных образцах обработка холодом приводит к неравноценному росту микродеформаций в различных фазах. В мартенсите микродеформации нарастают более интенсивно, чем в аустените.

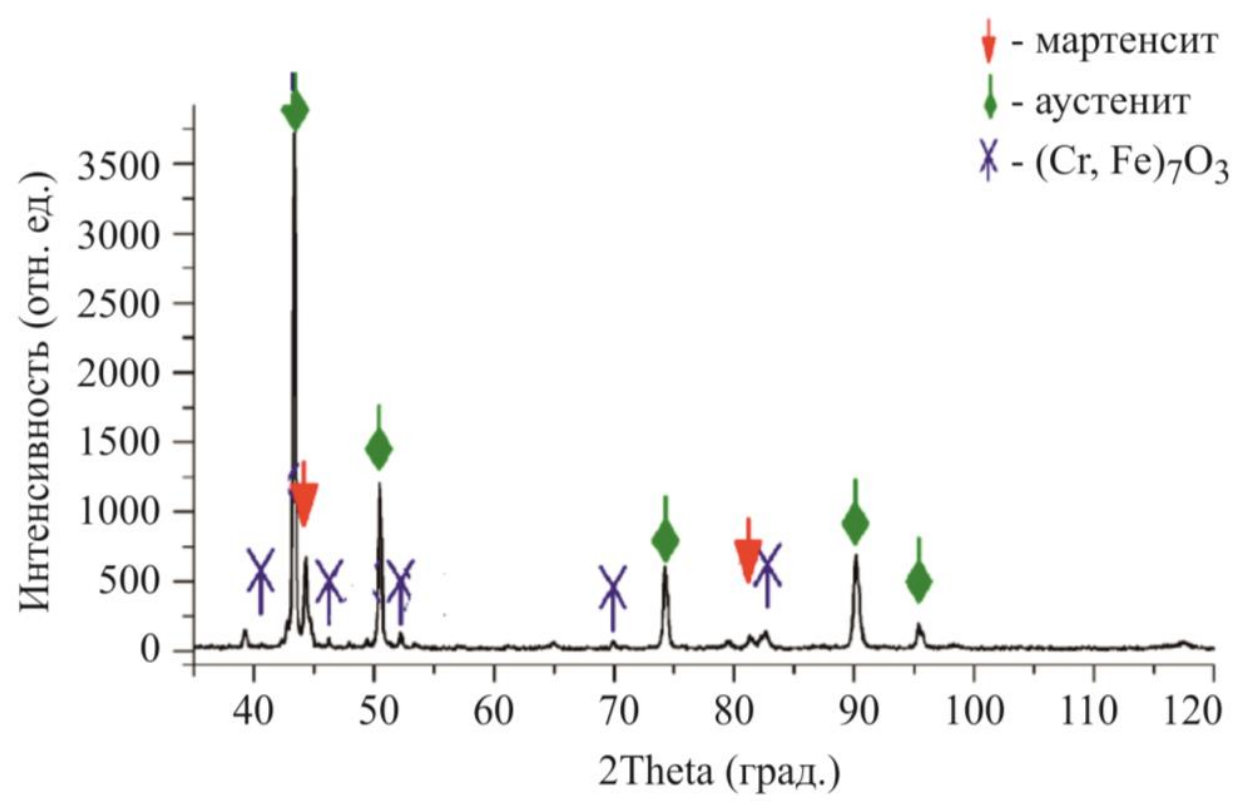

$a$

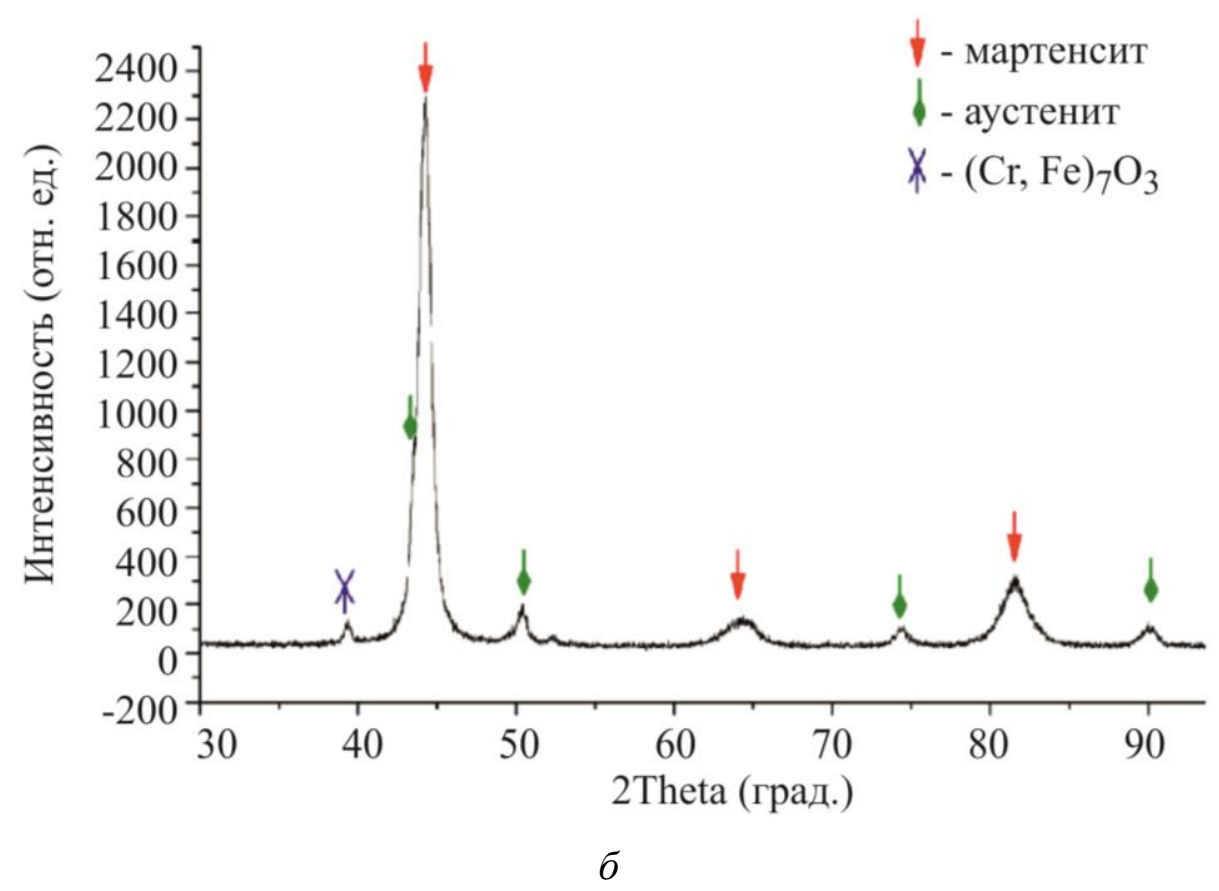

Рис. 5. Рентгеновские дифрактограммы образцов стали Х12МФЛ после закалки от $1170{ }^{\circ} \mathrm{C}(a)$ и обработки холодом $-70{ }^{\circ} \mathrm{C}(б)$ 
Такой фазовый состав обеспечивает дополнительное повышение абразивной износостойкости на 25 \% по сравнению с аналогичной закалкой без обработки холодом, так как дополнительные порции высокоуглеродистого мартенсита охлаждения, во-первых, создают повышенную начальную твёрдость и сжимающие напряжения на рабочей поверхности и, вовторых, стимулируют полное $\gamma \rightarrow \alpha_{\mathrm{M}}$ превращение, что подтверждает рентгеноструктурный анализ. Сохранение в матрице стали Х12МФЛ остаточного аустенита, по-видимому, положительно влияет на вязкость стали [9].

\section{4. Выводы}

1. Мартенситная структура сталей 150ХНМЛ и Х12МФЛ, полученная при закалке от нормальных температур (850-1000 $\left.{ }^{\circ} \mathrm{C}\right)$, обеспечивает высокую твёрдость (61-64 HRC), однако при этом не достигается максимальная износостойкость в условиях абразивного изнашивания.

2. Повышение температуры закалки сталей 150 ХНМЛ и Х12МЛ до $1170{ }^{\circ} \mathrm{C}$ вызывает прогрессирующее снижение исходной твёрдости - до 42 и $49 \mathrm{HRC}$ соответственно в связи с растворением части карбидов и соответствующим увеличением количества остаточного аустенита (до 25 и $60 \%$ соответственно), однако это сопровождается ростом износостойкости при абразивном изнашивании, особенно большим в стали Х12МФЛ. Это обусловлено сохранением в этой стали после закалки от высоких температур эвтектических карбидов и значительным количеством образующегося в процессе абразивного изнашивания мартенсита деформации.

3. Остаточный аустенит, получаемый в результате высокотемпературной закалки (от $1100-1170{ }^{\circ} \mathrm{C}$ ), в сталях 150 ХНМЛ и Х12МФЛ метастабилен и превращается в мартенсит деформации в процессе изнашивания, что придаёт сталям максимальную износостойкость вследствие обеспечения высокой способности к фрикционному упрочнению рабочей поверхности.

4. Определён оптимальный интервал температуры нагрева под закалку с точки зрения достижения высокой износостойкости, который составляет для обеих сталей $1050 \div 1150{ }^{\circ} \mathrm{C}$. Дальнейшее повышение температуры закалки выше $1150{ }^{\circ} \mathrm{C}$ нецелесообразно ввиду чрезмерного роста величины зерна.

5. Обработка холодом стали Х12МФЛ после высокотемпературной закалки с охлаждением до $-70{ }^{\circ} \mathrm{C}$ в течение 20 мин и низкого отпуска при температуре $200{ }^{\circ} \mathrm{C}$ в течение 2 ч позволяет дополнительно повысить абразивную износостойкость на $25 \%$ за счёт образования $15 \%$ высокоуглеродисто-хромистого мартенсита охлаждения и повышения начальной твёрдости до 60 HRC с сохранением 20 \% остаточного метастабильного аустенита и карбидов.

\section{Литература}

1. Deformation-induced phase transitions in a high-carbon steel / V. A. Shabashov, L. G. Korshunov, A. G. Mukoseev, V. V. Sagaradze, A. V. Makarov, V. P. Pilyugin, S. I. Novikov, N. F. Vildanova // Materials Science and Engineering: A. - 2003. - Vol. 246. - P. 196-207. DOI: 10.1016/S0921-5093(02)00549-X.

2. Влияние температуры закалки на фазовый состав, структуру и износостойкость стали 150ХНМ / М. А. Филиппов, М. А. Гервасьев, Ю. В. Худорожкова, В. В. Легчило // Известия высших учебных заведений. Черная металлургия. - 2013. - № 11. - С. 14-16.

3. Гуляев А. П. Металловедение. - М. : Металлургия, 1986. - 544 с.

4. Firouzdor V., Nejati E., Khomamizadeh F. Effect of deep cryogenic treatment on wear resistance and tool life of M2 HSS drill // Journal of Materials Processing Technology. - 2008. Vol. 206. - P. 467-472. - DOI: 10.1016/j.jmatprotec.2007.12.072.

5. Хрущев М. М., Бабичев М. А. Абразивное изнашивание. - М. : Наука, 1970. - 252 с. Filippov M.A. et al. / Controlling the structure of wear-resistant steels 150KhNML and Kh12MFL 
6. Коршунов Л. Г. Изнашивание металлов при трении / под ред. М. Л. Бернштейна, А. Г. Рахштадта. - М. : Металлургия, 1991. - Т. 1, кн. 2 : Металловедение и термическая обработка стали. - С. 387-413.

7. Филиппов М. А., Литвинов В. С., Немировский Ю. Р. Стали с метастабильным аустенитом. - М. : Металлургия, 1988. - 257 с.

8. Иванова В. С. Синергетика в металловедении // МиТОМ. - 2005. - № 2. - С. 12-19.

9. Бернштейн М. Л. Структура деформированных металлов. - М. : Металлургия, 1977. 490 c. 